FACTA UNIVERSITATIS

Series: Physical Education and Sport, Vol. 17, No 3, 2019, pp. 453 - 462

https://doi.org/10.22190/FUPES191107040D

Research article

\title{
A COMPARISON OF RACE PERFORMANCE CHARACTERISTICS BETWEEN ELITE MALE 50-M AND 100-M FREESTYLE SWIMMERS BASED ON THEIR RESULTS
}

\author{
UDC 797.2
}

\author{
Marko Đurović ${ }^{1}$, Damira Vranešić-Hadžimehmedović ${ }^{2}$ \\ Miloš Paunović ${ }^{1}$, Dejan Madić ${ }^{1}$, Tomislav Okičić ${ }^{1}$ \\ ${ }^{1}$ Faculty of Sport and Physical Education, University of Niš, Niš, Serbia \\ ${ }^{2}$ Faculty of Sport and Physical Education, University of Sarajevo, Sarajevo, \\ Bosnia and Herzegovina
}

\begin{abstract}
The aim of this research was to determine the differences in specific race performance characteristics of male swimmers in the 50-m and 100-m freestyle at the Serbia Open Championship 2017 (long-course). The overall sample included in this study consisted of 40 swimmers divided by a K-Means Cluster Analysis into three groups in relation to the results in the 50-m freestyle (G1_50,T50=23.53 $\pm 27 \mathrm{~s}, n=6$; G2_50, T50=24.54 $\left.\pm 33 s, n=18 ; G 3 \_50, T 50=25.52 \pm 33 s, n=16\right)$, and 55 swimmers also divided into three groups in relation to the results in the 100-m freestyle (G1_100, $T 100=50.99 \pm 82 s, n=10 ; G 2 \_100, T 100=53.41 \pm 48 s, n=17 ; G 3 \_100, T 100=56.13 \pm 1.32 s$, $n=28$ ). The research results indicate that there is a difference in the specific race performance characteristics in relation to the achieved results in the 50-m freestyle, including: $110 \_50(F=16.79, p=.000), S L 2 \_50(F=4.44, p=.019)$ and $S 12 \_50(F=13.49$, $p=.000)$, also in the 100- $m$ freestyle, including: t10_100 ( $F=36.45, p=.000), S L 1 \_100$ $(F=5.77, p=.005), S L 2 \_100(F=17.47, p=.000), S L 3 \_100(F=7.72, p=.001), S L 4 \_100$ $(F=9.84, p=.000), S I 1 \_100(F=5.12, p=.009), S I 2 \_100(F=45.97, p=.000), S I 3 \_100$ $(F=13.86, p=.000), S I 4 \_100(F=31.23, p=.000), S R 1 \_100(F=4.12, p=.022)$ and $S R 2 \_100(F=6.37, p=.003)$. Based on these results we can draw the conclusion that swimmers who have better control over their race performance characteristics during all the segments of the race, including stroke length, stroke index and stroke rate have the potential of being faster in the 50-m and 100-m freestyle.
\end{abstract}

Key words: Swimming, Stroke Rate, Stroke Index, Stroke Length

Received November 7, 2019/ Accepted December 25, 2019

Corresponding author: Marko Đurović

Faculty of Sport and Physical Education, University of Niš, Čarnojevića 10a, 18000 Niš, Serbia

Phone: + 38118 510-900•E-mail: djura86@yahoo.com

๑ 2019 by University of Niš, Serbia | Creative Commons License: CC BY-NC-ND 


\section{INTRODUCTION}

In competitive swimming, the final results of the race are connected to the start time, stroke and turn (Hay \& Guimares, 1983). However, irrespective of the recognizable significance of the start and turn, in a great many studies greater importance was assigned to the study of the stroke technique (Vilas-Boas et al., 2002). The stroke represents the basic unit of movement in swimming. Each stroke is characterized by amplitude, strength, rate and frequency (Maglisho, 2003). Furthermore, the stroke plays a part in the useful effect or propulsion, during which a greater pull force is generated, and the phase of reverse effect or retropulsion, during which the stroke surfaces return to their initial position and prepare for a new stroke. All of the cited characteristics of the stroke have a direct impact on the effectiveness of the stroke (Alberty, Sidney, Pelayo, \& Toussaint, 2009; Maglischo, 2003). The relationship between the speed, length and frequency of the stroke can be controlled using more or less propulsion phases. The final result in swimming is influenced by numerous elements. At the beginning of the race, start reaction time has an influence on the result, along with the power of the push-off and underwater kicking (Beretić, Đurović, Okičić, \& Dopsaj, 2013; Cossor \& Mason, 2001). During the swimming itself, the effectiveness of the stroke and the swimming technique impact the results (Đurović et al., 2017; Đurović, Beretić, Dopsaj, Pešić, \& Okičić, 2012; Jorgić et al., 2011; Jorgić, Okičić, Aleksandrović, \& Madić, 2010; Sánchez \& Arellano, 2002; Sanchez, 2000; Chollet et al., 1997). During the turn phase, great influence is exerted by the preparation made for the turn required for a specific technique, the performance of the turn, underwater kicking and the transition to the swimming phase (Nicol, Ball, \& Tor, 2019; Morais, Marinho, Arellano, \& Barbosa, 2019; Blanksby, Gathercole, \& Marshall, 1996). During the final phase of approach to the finish line, the greatest influence is achieved by a proper finish (Foster et al., 2003).

The results for shorter distances are mainly determined by neuromuscular and biomechanical factors, such as muscle force, propulsive effectiveness and swimming technique. Race performance characteristics in swimming include skills which directly influence the result in swimming, considering that the structure, character and intensity of load are very close to the activities which are performed at competitions and indicate the greatest connection with the achieved success (Malacko \& Rađo, 2004). The ability to transfer force in water is key for competitive swimming, in particular when it comes to short swimming distances. High values of force and power, which refer mainly to the upper part of the body, have been identified as the deciding factor for success in competitive swimming (Amaro et al., 2018). Lokken (1998) in his study determined the impact of power on the results of the 100-m and 200-m freestyle with a value of $74 \%$ and $72 \%$.

The analysis of race performance characteristics provides information on which abilities have the greatest impact on achieving better results in swimming, and thus, which require more attention during the training process. The aim of this paper was to determine the differences in the race performance characteristics among swimmers in relation to their achieved results, in order to improve their training process. 


\section{METHODS}

\section{The sample of participants}

The sample of participants numbered 40 swimmers, participants of the Heats, Semifinals and Finals of the 50-m freestyle, and 55 participants in the Heats, Semifinals and Finals of the 100-m freestyle at the Serbia Open Championship 2017. The participants in the 50-m freestyle were divided using a K-Means Cluster Analysis into three groups based on the achieved results. The first group included swimmers who were classified as the G1_50 group by the cluster analysis, whose mean swimming results were above average in relation to the other swimmers $(\mathrm{T} 50=23.53 \pm .27 \mathrm{~s}, \mathrm{n}=6$, mean standard $88.86 \%$ of the world record, Age $=23.3 \pm 4.5 \mathrm{yrs}$ ), the second group consisted of swimmers who were classified into the G2_50 group by the cluster analysis based on their overall sample (T50 $=24.54 \pm .33 \mathrm{~s}, \mathrm{n}=18$, mean standard $85.20 \%$ of the WR, Age $=18.6 \pm 2.4 \mathrm{yrs}$ ) and the third group G3_50 which was made up of swimmers who achieved above average results in the 50-m freestyle when compared to the other swimmers ( $\mathrm{T} 50=25.52 \pm .33 \mathrm{~s}, \mathrm{n}=16$, mean standard $81.93 \%$ of the WR, Age $=17.3 \pm 1.9 \mathrm{yrs})$. The participants in the $100-\mathrm{m}$ freestyle were also divided into three groups based on the same criterion: G1_100 (T100=50.99 \pm .82 s, n=10, mean standard $91.99 \%$ of the world record), G2_100 (T100 $=53.41 \pm .48 \mathrm{~s}, \mathrm{n}=17$, mean standard $87.82 \%$ of the world record), and G3_100 (T100=56.13 $\pm 1.32 \mathrm{~s}, \mathrm{n}=28$, mean standard $83.57 \%$ of the world record).

\section{Procedures}

All the races were recorded using the action camera GoPro (HERO4 Black Edition) at a rate of 120 frames per second. The camera was positioned on the sagittal plane in relation to the length of the pool, for the $25-\mathrm{m}$ (one half of the length of the pool). The calibration and marking of the space was performed using set lanes in the pool, with floating markers of various colors at various distances: 5-m, 15-m, 25-m, 35-m and 45-m. The 50-m freestyle was divided into segments, two segments of $25-\mathrm{m}$ each (the first 25 $\mathrm{m}$ and the second $25-\mathrm{m}$ ). The 100-m freestyle was divided into four equal parts (each of $25 \mathrm{~m})$. Each race was analyzed with the specialized software Kinovea, Version 0.8.15.

\section{The sample of variables}

The main race performance characteristics were obtained using an analysis of the video recordings and formulae proposed by Costil, Maglischo, \& Richardson (1992).

- Stroke length expressed in $.01 \mathrm{~m}(\mathrm{SL}=\mathrm{D}-\mathrm{d} 1 / \mathrm{N})$; Legend: D - length of the swim, $\mathrm{d} 1$ - length of the underwater glide following the start, $\mathrm{N}$ - number of strokes according to D-d1.

- Stroke index expressed in arbitrary units (SI = SS x SL); Legend: SS - swim speed calculated using the formula: $\mathrm{D} / \mathrm{T}(\mathrm{D}$ - swimming distance, $\mathrm{T}$ - swim time); $\mathrm{SL}$ - stroke length.

- Stroke rate expressed as stroke/min ( $\mathrm{SR}=\mathrm{N} / \mathrm{T}-\mathrm{t} 1 \mathrm{x} 60)$; Legend: $\mathrm{N}$ - number of strokes according to D-d1, T - swim time, t1 - time of the underwater glide following the start, 60 - stroke rate per minute.

- Start time expressed in seconds (t10); Legend: t10 - start time corresponding to 10 meters. 
- Results of 50-m freestyle expressed in seconds (T50); Legend: T50 - time taken from the official results of man 50 freestyle event

- Results of 50-m freestyle expressed in seconds (T100). Legend: T100 - time taken from the official results of man 100 freestyle event.

\section{Statistical analyses}

For all the variables, the basic parameters of descriptive statistics were calculated. In order to calculate the statistically significant difference for each variable between the groups, the one-way ANOVA method and POST HOC (Tukey HSD) test were used. Statistical calculation was done by means of the Statistics software SPSS 15.0.

\section{RESULTS}

Table 1 Basic descriptive statistical parameters and the results of the ANOVA of the applied variables in the 50-m freestyle man

\begin{tabular}{|c|c|c|c|c|c|c|c|c|c|c|c|}
\hline \multirow[t]{2}{*}{ Variables } & \multirow[t]{2}{*}{ Groups } & \multirow[t]{2}{*}{$\mathrm{N}$} & \multirow[t]{2}{*}{ Mean } & \multirow[t]{2}{*}{ SD } & \multirow[t]{2}{*}{$\mathrm{CV}$} & \multicolumn{2}{|c|}{ ANOVA } & \multicolumn{4}{|c|}{ Tukey HSD } \\
\hline & & & & & & $\mathrm{F}$ & $\mathrm{p}$ & vs & & I-J & Sig. \\
\hline \multirow{3}{*}{$\mathrm{t} 10 \_50(\mathrm{~s})$} & G1_50 & 6 & 3.97 & .07 & $1.82 \%$ & \multirow{3}{*}{16.79} & \multirow{3}{*}{.000} & \multirow{2}{*}{ G1_50 } & G2_50 & $-.19^{*}$ & .016 \\
\hline & $\mathrm{G} 2-50$ & 18 & 4.17 & .12 & $2.79 \%$ & & & & G3_50 & $-.37^{*}$ & .000 \\
\hline & G3_50 & 16 & 4.35 & .18 & $4.10 \%$ & & & G2_50 & G3_50 & $-.18^{*}$ & .002 \\
\hline \multirow{3}{*}{$\begin{array}{c}\text { SL1_50 } \\
(\mathrm{m})\end{array}$} & G1_50 & 6 & .98 & .15 & $15.52 \%$ & \multirow{3}{*}{1.40} & \multirow{3}{*}{.260} & & G2_50 & .06 & .461 \\
\hline & G2_50 & 18 & .92 & .10 & $10.42 \%$ & & & & G3_50 & .08 & .230 \\
\hline & G3_50 & 16 & .90 & .08 & $8.85 \%$ & & & G2_50 & G3_50 & .02 & .775 \\
\hline \multirow{3}{*}{$\begin{array}{c}\text { SL2_50 } \\
(\mathrm{m})\end{array}$} & G1_50 & 6 & 1.08 & .07 & $6.14 \%$ & \multirow{3}{*}{4.44} & \multirow{3}{*}{.019} & & G2_50 & $.08^{*}$ & .048 \\
\hline & G2_50 & 18 & .99 & .06 & $6.29 \%$ & & & & G3_50 & $.10^{*}$ & .015 \\
\hline & G3_50 & 16 & .98 & .08 & $8.26 \%$ & & & G2_50 & G3_50 & .02 & .747 \\
\hline \multirow{3}{*}{ SI1_50 } & G1_50 & 6 & 1.31 & .39 & $29.44 \%$ & \multirow{3}{*}{1.14} & \multirow{3}{*}{0.331} & & G2_50 & .15 & .423 \\
\hline & G2_50 & 18 & 1.16 & .26 & $22.42 \%$ & & & & G3_50 & .18 & .308 \\
\hline & G3_50 & 16 & 1.13 & .17 & $14.95 \%$ & & & G2_50 & G3_50 & .03 & .940 \\
\hline \multirow{3}{*}{ SI2_50 } & G1_50 & 6 & 2.13 & .15 & $6.86 \%$ & \multirow{3}{*}{13.49} & \multirow{3}{*}{.000} & & G2_50 & $.25^{*}$ & .001 \\
\hline & G2_50 & 18 & 1.88 & .13 & $6.75 \%$ & & & & G3_50 & $.34^{*}$ & .000 \\
\hline & G3_50 & 16 & 1.78 & .15 & $8.20 \%$ & & & G2_50 & G3_50 & .09 & .124 \\
\hline \multirow{3}{*}{$\begin{array}{l}\text { SR1_50 } \\
\text { stroke/min }\end{array}$} & G1_50 & 6 & 124.23 & 12.18 & $9.81 \%$ & \multirow{3}{*}{.02} & \multirow{3}{*}{0.976} & & G2_50 & -.21 & .999 \\
\hline & G2_50 & 18 & 124.43 & 8.80 & $7.07 \%$ & & & & G3_50 & -.82 & .982 \\
\hline & G3_50 & 16 & 125.05 & 9.28 & $7.42 \%$ & & & G2_50 & G3_50 & -.61 & .981 \\
\hline \multirow{3}{*}{$\begin{array}{c}\text { SR2_50 } \\
\text { stroke/min }\end{array}$} & G1_50 & 6 & 110.74 & 6.13 & $5.54 \%$ & \multirow{3}{*}{.54} & \multirow{3}{*}{.585} & & G2_50 & -4.07 & .560 \\
\hline & G2_50 & 18 & 114.81 & 7.50 & $6.54 \%$ & & & & G3_50 & -2.69 & .780 \\
\hline & G3_50 & 16 & 113.43 & 9.76 & $8.60 \%$ & & & G2_50 & G3_50 & 1.38 & .881 \\
\hline & G1_50 & 6 & 23.53 & .27 & $1.15 \%$ & & & & G2_50 & $-1.02^{*}$ & .000 \\
\hline T50 (s) & $\mathrm{G} 2-50$ & 18 & 24.54 & .33 & $1.34 \%$ & 91.67 & .000 & & G3_50 & $-1.99^{*}$ & .000 \\
\hline & G3_50 & 16 & 25.52 & .33 & $1.31 \%$ & & & G2_50 & G3_50 & $-.97^{*}$ & .000 \\
\hline
\end{tabular}

Legend: Groups - groups of swimmers, N - number of participants, Mean - means; SD - standard deviation, CV - coefficient of variation, Anova F - F statistic, Anova p - level of significance, I-J - Mean Difference between the groups, Sig. - level of significance of the Tukey HSD, t10 50 - time to $10 \mathrm{~m}$, SL1 50 - stroke length for the first $25 \mathrm{~m}$, SL2 50 - stroke length for the second $25 \mathrm{~m}$, SI1_50 - efficiency of the stroke in the first $25 \mathrm{~m}$, SI2_50 - efficiency of the stroke in the second $25 \mathrm{~m}$, $\mathrm{SR} 1 \_50$ - stroke rate in the first $25 \mathrm{~m}, \mathrm{SR} 2 \_50$ - stroke rate in the second $25 \mathrm{~m}, \mathrm{~T} 50$ - achieved time in the $50 \mathrm{~m}$ freestyle. 
Table 1 shows the results of the descriptive statistical parameters for race performance characteristics and swimming results. By analyzing the values of the variation coefficient (CV) we can see that they were below $30 \%$, which indicates that the results were confident and can be used for further analysis (Dopsaj \& Bratuša, 2003). In addition, Table 1 shows the results of the ANOVA for the applied variables for the evaluation of the performance rate, where we can note a statistically significant difference between the groups for the variables: t10_50 $(\mathrm{F}=16.79, \mathrm{p}=.000)$, SL2_50 $(\mathrm{F}=4.44, \mathrm{p}=.019)$ and SI2_50 ( $\mathrm{F}=13.49$, $\mathrm{p}=.000)$. By analyzing the results of the Post Hoc ANOVA test (Tukey HSD), we can conclude that for the variable t10_50 a statistically significant difference was noted in favor of the group G1_50 compared to the other groups (G1_50 - G2_50=-.19 s, p=.016; G1_50 - G3_50=-.37 s, p=.000), while group G2_50 achieved a statistically significant difference compared to group G3_50 (G2_50-G3_50=-.18 s, p=.002). When it comes to the achieved statistically significant difference for the variable SL2_50, it can be noted that it too was in favor of group G1_50 (G1_50-G2_50=.08 m, p=.048; G1_50-G3_50=0.10 m, $\mathrm{p}=.015)$, while group G2_50 did not achieve any statistically significant differences compared to group G3_50 (G2_50-G3_50=0.02 m, p=.747). By analyzing the differences between the groups for the variable SI2_50, it can be concluded that a statistically significant difference was determined in favor of the group G1_50 (G1_50-G2_50=.25, $\mathrm{p}=.001 ; \mathrm{G} 1 \_50-\mathrm{G} 3 \_50=.34, \mathrm{p}=.000$ ), while group G2_50 did not achieve any statistically significant difference in relation to group G3_50 (G2_50-G3_50=.09, p=.124).

Based on the presented results it can be concluded that there is a statistically significant difference in the specific motor skills compared to the achieved results in the 50-m freestyle for the variables t10_50 (start time to 10 meters), SL2_50 (stroke length in the second 25 meters) and SI2_50 (stroke index in the second 25 meters).

Table 2 shows the descriptive statistic results of race performance and swimming results. By analyzing the values of the coefficient of variation $(\mathrm{CV})$ it can be seen that it does not exceed $30 \%$ which indicates that the results are reliable and can be used for further analysis (Dopsaj \& Bratuša, 2003). By analyzing the results in Table 2, which shows the results of the ANOVA between the groups in the variables for the evaluation of rate of performance, it can be noted that with the exception of the variables SR3_100 $(\mathrm{F}=2.38, \mathrm{p}=.103)$ and SR4_100 $(\mathrm{F}=.83, \mathrm{p}=.441)$, for which no statistically significant difference was determined, for all the other applied variables there is a statistically significant difference between the groups, including: t10_100 $(\mathrm{F}=36.45, \mathrm{p}=.000)$, SL1_100 ( F=5.77, p=.005), SL2_100 ( F=17.47, p=.000), SL3_100 (F=7.72, p=.001), SL4_100 ( $F=9.84, p=.000)$, SI1_100 ( F=5.12, p=.009), SI2_100 (F=45.97, p=.000), SI3_100 $(\mathrm{F}=13.86, \mathrm{p}=.000), \mathbf{S I 4} \_\mathbf{1 0 0}(\mathrm{F}=31.23, \mathrm{p}=.000), \mathbf{S R 1} \mathbf{1 0 0}(\mathrm{F}=4.12, \mathrm{p}=.022)$ and SR2_100 $(\mathrm{F}=6.37, \mathrm{p}=.003)$. By analyzing the results of the Post Hoc ANOVA test (Tukey HSD), it can be concluded that for two of the applied variables a statistically significant difference was realized between all the groups, including: t10_100 (G1_100G2_100=-.25 s, p=0.001; G1_100-G3_100=-.49 s, p=0.000; G2_100-G3_100=-.24 s, $\mathrm{p}=.000)$ and SI4_100 (G1_100-G2_100=.29, p=.000; G1_100-G3_100=.44, p=.000; G2_100-G3_100=.15, $\mathrm{p}=.007)$. For the remaining variables, a statistically significant difference was realized only favor of the group G1_100 (SL1_100, SL2_100, SL3_100, SL4_100, SI1_100, SI2_100, SI3_100, SR1_100, SR2_100). 
Table 2 Basic statistical descriptive statistical parameters and the results of the ANOVA for the applied variables in the 100-m freestyle man

\begin{tabular}{|c|c|c|c|c|c|c|c|c|c|}
\hline \multirow[t]{2}{*}{ Variable } & \multirow[t]{2}{*}{ Group } & \multirow[t]{2}{*}{$\mathrm{N}$} & \multirow[t]{2}{*}{ Mean } & \multirow{2}{*}{$\begin{array}{l}\text { Std. } \\
\text { Dev. }\end{array}$} & \multirow[t]{2}{*}{$\mathrm{CV}$} & ANOVA & \multicolumn{3}{|c|}{ Tukey HSD } \\
\hline & & & & & & $\mathrm{F}$ & vs. & I-J & Sig. \\
\hline \multirow{3}{*}{ t10_100 (s) } & $1 \_100$ & 0 & 3.98 & .15 & $3.8 \%$ & \multirow{3}{*}{36.45} & \multirow{2}{*}{$.000 \mathrm{G} 1 \_100 \mathrm{G} 3 \_100$} & $-.25^{*}$ & \multirow{2}{*}{$\begin{array}{l}.001 \\
.000\end{array}$} \\
\hline & G2_100 & 17 & 4.23 & .15 & $3.6 \%$ & & & $-.49^{*}$ & \\
\hline & G3_100 & 28 & 4.47 & .17 & $3.9 \%$ & & G2_100 G3_100 & $-.24^{*}$ & .000 \\
\hline \multirow{3}{*}{$\begin{array}{l}\text { SL1_100 } \\
(\mathrm{m})\end{array}$} & G1_100 & 10 & 1.11 & .07 & $6.3 \%$ & \multirow{3}{*}{5.77} & \multirow{2}{*}{.005 G1_100 $\begin{array}{l}\text { G2_100 } \\
\text { G3_100 }\end{array}$} & $.12^{*}$ & \multirow{2}{*}{$\begin{array}{l}.006 \\
.013\end{array}$} \\
\hline & G2_100 & 17 & 0.99 & .09 & $8.9 \%$ & & & $.10^{*}$ & \\
\hline & G3_100 & 28 & 1.01 & .10 & $9.7 \%$ & & G2_100 G3_100 & -.02 & .790 \\
\hline \multirow{3}{*}{$\begin{array}{l}\text { SL2_100 } \\
(\mathrm{m})\end{array}$} & $\overline{\text { G1_1C }}$ & 10 & 1.30 & .10 & $7.8 \%$ & \multirow{3}{*}{17.47} & \multirow{2}{*}{$.000 \mathrm{G} 1 \_100 \begin{array}{l}\mathrm{G} 2 \_100 \\
\mathrm{G} 3 \_100\end{array}$} & $.19^{*}$ & \multirow{2}{*}{$\begin{array}{l}.000 \\
.000\end{array}$} \\
\hline & G2_100 & 17 & 1.11 & .08 & $7.3 \%$ & & & $.16^{*}$ & \\
\hline & G3_100 & 28 & 1.13 & .08 & $7.3 \%$ & & G2_100 G3_100 & -.02 & .618 \\
\hline \multirow{3}{*}{$\begin{array}{l}\text { SL3_100 } \\
(\mathrm{m})\end{array}$} & G1_100 & 10 & 1.15 & .09 & $7.6 \%$ & \multirow{3}{*}{7.72} & G2_100 & $.10^{*}$ & .005 \\
\hline & G2_100 & 17 & 1.05 & .08 & $7.3 \%$ & & G3_100 & $.10^{*}$ & .001 \\
\hline & G3_100 & 28 & 1.05 & .07 & $6.4 \%$ & & G2_100 G3_100 & .01 & .943 \\
\hline & G1_100 & 10 & 1.14 & .05 & $4.8 \%$ & & G1_100 & $.11^{*}$ & .007 \\
\hline SL4_100 & G2_100 & 17 & 1.04 & .08 & $7.4 \%$ & 9.84 & $.000{ }^{\mathrm{G} 1}{ }^{100} \mathrm{G} 3 \_100$ & $.14^{*}$ & .000 \\
\hline & G3_100 & 28 & 1.01 & .10 & $9.5 \%$ & & G2_100 G3_100 & .03 & .453 \\
\hline & & 10 & 2.10 & .24 & $11.4 \%$ & & G1 100 G2_100 & $.27^{*}$ & .016 \\
\hline SI1_ & $\mathrm{G} 2$ & 17 & 1.83 & .22 & $12.0 \%$ & 5.12 & ${ }^{100} \mathrm{G} 3 \_100$ & $.26^{*}$ & .012 \\
\hline & G3_ & 28 & 1.84 & .24 & $13.2 \%$ & & G2_100 G3_100 & -.01 & .990 \\
\hline & G1_100 & 10 & 2.42 & .16 & $6.5 \%$ & & G2_100 & $.45^{*}$ & .000 \\
\hline SI2_100 & G2_100 & 17 & 1.97 & .14 & $7.1 \%$ & 45.97 & $.000^{\mathrm{G} 1}{ }^{100} \mathrm{G} 3 \_100$ & $.49^{*}$ & .000 \\
\hline & G3_1 & & 1.9 & .14 & $7.3 \%$ & & G2_100 G3_100 & .04 & .557 \\
\hline & & & & .19 & $9.1 \%$ & & G1 100 G2_100 & $.22^{*}$ & .002 \\
\hline SI3_ & G2 & 17 & & .16 & $8.7 \%$ & 13.86 & ${ }^{100} \mathrm{G} 3$ & $.31^{*}$ & .000 \\
\hline & G3 & 28 & 1.80 & .14 & $8.0 \%$ & & $100 \mathrm{G} 3 \_100$ & .08 & .207 \\
\hline & G1_100 & 10 & 2.06 & .13 & $6.4 \%$ & & G2_100 & $.29^{*}$ & .000 \\
\hline SI4_100 & G2_100 & 17 & 1.77 & .15 & $8.7 \%$ & 31.23 & $.000{ }^{\mathrm{G} 1}{ }^{100} \mathrm{G} 3{ }_{-} 100$ & $.44^{*}$ & .000 \\
\hline & G3_10 & 28 & 1.62 & .16 & $9.8 \%$ & & G2_100 G3_100 & $.15^{*}$ & .007 \\
\hline & G1_1 & 10 & 02.24 & 4.63 & $4.5 \%$ & & $100 \mathrm{G} 2 \_100$ & $-9.97^{*}$ & .016 \\
\hline & $\mathrm{G} 2 \_1$ & 17 & & 9.31 & $8.3 \%$ & 4.12 &. $\mathbf{0 2 2}{ }^{\mathrm{G} 1}{ }^{100} \mathrm{G} 3{ }_{-} 100$ & -6.66 & .106 \\
\hline & G3_1 & 28 & 89 & 9.39 & $8.6 \%$ & & G2_100 G3_100 & 3.31 & .439 \\
\hline & G1_100 & 10 & 87.20 & 8.12 & $9.3 \%$ & & G2_100 & $-10.05^{*}$ & .004 \\
\hline & G2_100 & 17 & 97.25 & 7.70 & $7.9 \%$ & 6.37 & $.003^{\mathrm{G} 1}{ }^{100} \mathrm{G} 3 \_100$ & -3.75 & .376 \\
\hline & G3_100 & 28 & 90.95 & 7.26 & $8.0 \%$ & & G2_100 G3_100 & $6.30^{*}$ & .024 \\
\hline & G1_100 & 10 & 95.75 & 8.62 & $9.0 \%$ & & G2_100 & -6.21 & .093 \\
\hline & & 17 & & 6.86 & $6.7 \%$ & 2.38 & $.103^{\mathrm{G} 1}-100 \mathrm{G} 3 \_100$ & -3.03 & .502 \\
\hline & G3_1 & 28 & .78 & 7.07 & $7.2 \%$ & & G2_100 G3_100 & 3.18 & .340 \\
\hline & G1_100 & 10 & 94.61 & 4.36 & $4.6 \%$ & & G2_100 & -4.32 & .439 \\
\hline & G2_100 & 17 & 98.93 & 6.88 & $7.0 \%$ & 0.83 & $0.441^{\mathrm{G} 1}{ }^{100} \mathrm{G} 3{ }_{-}^{-} 100$ & -1.84 & .838 \\
\hline & G3_1 & 28 & 96.45 & 10.69 & $11.1 \%$ & & G2_100 G3_100 & 2.48 & .631 \\
\hline & G1_100 & 10 & 50.99 & .82 & $1.6 \%$ & & G2_100 & $-2.42^{*}$ & .000 \\
\hline 1100 & G2_100 & 17 & 53.41 & .48 & $.9 \%$ & 99.55 & $.000^{\mathrm{G} 1}{ }^{100} \mathrm{G} 3{ }_{-} 100$ & $-5.14^{*}$ & .000 \\
\hline & G3_100 & 28 & 56.13 & 1.32 & $2.3 \%$ & & $\mathrm{G} 2 \_100 \mathrm{G} 3 \_100$ & $-2.72^{*}$ & .000 \\
\hline
\end{tabular}


Based on the aforementioned, we can conclude that there is a statistically significant difference in the rate of performance compared to the results in the $100-\mathrm{m}$ freestyle for almost all the variables which represent the race performance of the swimmers (t10_100, SL1_100, SL2_100, SL3_100, SL4_100, SI1_100, SI2_100, SI3_100, SI4_100, SR1_100, SR2_100).

\section{DISCUSSION}

The goal of the realized study was to determine the differences in the race performance characteristics of swimmers in relation to their achieved results in the 50-m freestyle and the 100-m freestyle. As previously indicated, all the participants competed in the Serbia Open Championship 2017 and were divided by a K-Means Cluster Analysis into three groups based on their achieved results in the 50-m freestyle (G1_50, T50=23.53 $\pm .27 \mathrm{~s}, \mathrm{n}=6$; $\mathrm{G} 2 \_50, \mathrm{~T} 50=24.54 \pm .33 \mathrm{~s}, \mathrm{n}=18 ; \mathrm{G} 3 \_50, \mathrm{~T} 50=25.52 \pm .33 \mathrm{~s}, \mathrm{n}=16$ ), and the $100-\mathrm{m}$ freestyle (G1_100, T100=50.99 \pm .82 s, n=10; G2_100, T100=53.41 \pm .48 s, n=17; G3_100, $\mathrm{T} 100=56.13 \pm 1.32 \mathrm{~s}, \mathrm{n}=28$ ). The research results indicate that there is a difference in the rate of performance characteristics compared to the results in the 50-m freestyle and the $100-\mathrm{m}$ freestyle. Existing research indicates that the swim speed is influence by race performance characteristics, on which the achieved results directly depend (Đurović et al., 2017; Đurović et al., 2012; Jorgić et al., 2011; Jorgić et al., 2010; Sanchez, 2000; Sánchez \& Arellano, 2002; Chollet et al., 1997;). By analyzing the results of the study of Jorgić et al. (2011) carried out on a sample of 14 elite swimmer, it can clearly be seen that race performance characteristics (SL, SI, SR) have a statistically significant effect on the 50-m freestyle $(\mathrm{R}=.99, \mathrm{R} 2=.98, \mathrm{~F}=134.30, \mathrm{p}=.000)$. In the study carried out by Đurović et al. (2017) a statistically significant correlation was determined between the swimming results of the finalists in the 50-m freestyle and the variable SL ( $r=-.43, p=.05)$, SI $(r=-.59, p=.01)$ and $\mathrm{SE}(\mathrm{r}=-.45, \mathrm{p}=.04)$ while the regression analysis indicates the statistically significant influence of the SL and SI on swimming speed $(\mathrm{R}=.991, \mathrm{R} 2=.978, \mathrm{~F}=226.40, \mathrm{p}=.000)$. The research results support the results of the existing studies and indicate that quicker swimmers are those who during the second half of the 50-m freestyle maintain a longer stroke length (SL2_50) and greater stroke index (SI2_50), which is the product of the swim speed and stroke length. In addition, in the study of Jorgić et al. (2010) which included younger swimmers (aged 9-12) it was proven that race performance characteristics have a greater impact $(\mathrm{R}=.94, \mathrm{R} 2=0.88, \mathrm{~F}=34.34, \mathrm{p}=.00)$ than basic performance characteristics $(\mathrm{R}=.85, \mathrm{R} 2=.61, \mathrm{~F}=6.7, \mathrm{p}=.00)$ on swim speed in the 100 -m freestyle, as well as with senior swimmers. The research results indicate the importance of race performance characteristics for the realization of better results in the 100-m freestyle, where a statistically significant difference was noted among almost all the tested characteristics (SL, SI and SR) in all parts of the race. By analyzing the results of Đurović et al. (2012), a study which was carried out on a sample of elite swimmers (mean value result $=98.9 \%$ of the World Record for the 100-m freestyle) we can note a statistically significant correlation between the length of the stroke in the last 25 meters (SL4), the stroke index in the third 25 meters of the race (SI3), and swim speed. The decrease in speed during a race is directly related to the decrease in stroke length (Craig, Skehan, Pawelczyk, \& Boomer, 1985; Hay et al., 1983). The differences in the race performance characteristics (SI, SR and SL) can be used as an 
indicator of the level of quality of the swimmers (Sanchez, 2000; Chollet et al., 1997). The research results indicate that there is also a statistically significant difference between the groups in the dive start, that is, that the fastest swimmers also had the fastest start realization (G1_50-G2_50=-.19 s, p=.016; G1_50-G3_50=-.37 s, p=.000; G2_50-G3_50=-0.18 s, $\mathrm{p}=.002$ ). The research which focused on the study of the swimming start also indicates the strong influence of starting skills on the final results in sprinting disciplines (Tor, Pease, \& Ball, 2015; Beretić et al., 2013; Blanksby, Nicholson, \& Elliott, 2002; Cossor \& Mason 2001). Based on this kind of information, it could be concluded that successful freestyle swimmers are recognizable based on their stroke length, greater stroke index and lower stroke rate in all the segments of the race. A greater value of the stroke index is related to effective energy consumption, that is, effectiveness of the swimming technique (Costill et al., 1985). Swimmers who have better control of their race performance characteristics during all the segments of the race, including stroke length, stroke index and stroke rate (stroke frequency), have the potential to be faster in the 50-m and 100-m freestyle. Based on the above mentioned, the analysis of these characteristics should be a component part of the plan and program of swimming training, since the obtained results provide useful information necessary for achieving maximum competitive results.

\section{CONCLUSION}

The research was carried out with the aim of determining the differences in race performance characteristics among swimmers in relation to the achieved results in the 50$\mathrm{m}$ and 100-m freestyle. Based on the results of the ANOVA (Tukey HSD), it can be concluded that there is a statistically significant difference in race performance characteristics, including: t10_50, SL2_50 and SI2_50 compared to the results in the 50$\mathrm{m}$ freestyle. In addition, we can conclude that there is a statistically significant difference between the race performance characteristics and the 100-m freestyle, including: t10_100, SL1_100, SL2_100, SL3_100, SL4_100, SI1_100, SI2_100, SI3_100, SI4_100, SR1_100 and SR2_100 in relation to the results. The obtained results are certainly useful for swimmers and coaches in realizing training as well as in planning and programming the training process for the most important competitions of the season. The results of this research provide information regarding the extent to which work on the development of certain race performance characteristics has on the results of swimmers in the 50-m and 100-m freestyle. The differences in race performance characteristics in relation to the values of the results provide coaches with a broader picture of the quality of the swimmers' performance in the given disciplines, as well as feedback on the effective performance of parts of the race which will later be treated in the training process, and with the aim of improving certain race performance characteristics.

\section{REFERENCES}

Alberty M., Sidney M., Pelayo P., \& Toussaint H. M. (2009). Stroking characteristics during time to exhaustion tests. Medicine \& Science in Sports \& Exercise, 41(3), 637-644.

Amaro, N.M., Morouço, P.G., Marques, M.C., Batalha, N., Neiva, H., \& Marinho, D.A. (2019). A systematic review on dry-land strength and conditioning training on swimming performance. Science \& Sports, 34(1), e1-e14. 
Beretić, I., Đurović, M., Okičić, T., \& Dopsaj, M. (2013). Relations between lower body isometric muscle force characteristics and start performance in elite male sprint swimmers. Journal of Sports Science \& Medicine, 12(4), 639

Blanksby, B.A., Gathercole, D.G., \& Marshall, R.N. (1996). Force plate and video analysis of the tumble turn by age-group swimmers. Journal of Swimming Research, 11, 40-45.

Blanksby, B., Nicholson, L., \& Elliott, B. (2002). Swimming: Biomechanical analysis of the grab, track and handle swimming starts: an intervention study. Sports Biomechanics, 1(1), 1124.

Chollet, C., Pelayo, P., Delaplace, C., Tourny, C., \& Sidney, M. (1997). Stroking characteristic variations in the 100-M freestyle for male swimmers of differing skill. Perceptual and Motor Skills, 85(1), 167-177.

Cossor J., \& Mason B. (2001). Swimstart performance at the Sydney 2000 Olimpic. In: J.P. Blackwell \& P.X. Sanders (Eds.), Proceedings of the 19 International Symposium on Biomechanics in Sports, (pp. 70-74), USA: San Francisco.

Costill, D., Kovaleski, Porter, Kirwan, Fielding, \& King, D. (1985). Energy expenditure during front crawl swimming: Predicting success in middle-distance events. International Journal of Sports Medicine, 6(5), 266-270.

Costill, D.L, Maglischo, E.W, \& Richardson, A.B. (1992). Swimming. Oxford: Blackwell Science.

Craig, A.B., Skehan, P.L., Pawelczyk, J.A., \& Boomer, W.L. (1985). Velocity, stroke rate and distance per stroke during elite swimming competition. Medicine and Science in Sports and Exercise, 17, 625-634.

Dopsaj, M., \& Bratuša, Z. (2003). Matematički model za procenu nivoa generalne plivačke pripremljenosti vaterpolista mlađeg uzrasta od 12 do 14 godina (A mathematical model for assessing the level of general swimming readiness of water polo players aged 12 to 14 years). Nova sportska praksa, (1-2), 47-55. In Serbian

Đurović, M., Beretić, I., Dopsaj, M., Pešić, M., \& Okičić, T. (2012). A comparison of kinematic variables between european elite, national elite and regional elite male 100m freestyle swimmers. Facta Universitatis Series Physical Education and Sport, 10 (4), 339-346.

Đurović, M., Okičić, T., Madić, D., Beretić, I., Pešić, M., \& Trivun, M. (2017). Influence of situation motor abilities on $50 \mathrm{~m}$ freestyle results. In: S. Pantelić (Ed.), 20 Scientific Conference „FISCommunications 2017" in Physical Education, Sport and Recreation, (pp. 51-54), Niš: Faculty of Sport and Physical Education, University of Niš.

Foster, C., De Koning, J.J., Hettinga, F., Lampen, J., La Clair, K.L., Dodge, C., et al. (2003). Pattern of energy expenditure during simulated competition. Medicine and Science in Sports and Exercise, 35(5), 826-831.

Hay, J.G, \& Guimares, A.C.S. (1983). A quantitative look at swimming biomechanics. Swimming Technique, 20, 11-17.

Jorgić, B., Okičić, T., Aleksandrović, M., \& Madić, D. (2010). Influence of basic and specific motor abilities on swimming results. Acta Kinesilogica, 4(2), 73-77.

Jorgić, B., Okičić, T., Stanković, R., Dopsaj, M., Madić, D., \& Thanopoulos, V. (2011). Parameters of situational motor skills of Serbian swimmers and their influence on swimming results. Facta Universitatis Series Physical Education and Sport, 9 (4), 399-405.

Lokken, B. (1998). Swiming fitness testing. Exercise Physiology, 652, 2-8.

Maglischo, E.W. (2003). Swimming fastest. Champaing: Human Kinetics.

Malacko, J., \& Rađo, I. (2004). Tehnologija sporta i sportskog treniniga (Technology of sports and sports training). Sarajevo: Faculty of Sport and Physical Education. In Serbian

Morais, J.E., Marinho, D. A., Arellano, R., \& Barbosa, T.M. (2019). Start and turn performances of elite sprinters at the 2016 European Championships in swimming. Sports Biomechanics, 18(1), 100-114.

Nicol, E., Ball, K., \& Tor, E. (2019). The biomechanics of freestyle and butterfly turn technique in elite swimmers. Sports Biomechanics, DOI: 10.1080/14763141.2018.1561930.

Sanchez, J.A. (2000). Analysis de la actividad competitiva en natacion: Diferencias en funcion de la longitud, el nivel de ejecucion, el sexo, el estilo y la distancia de prueba (Analysis of the competitive activity in swimming: Differences in terms of the length, the level of execution, the sex, the style and the distance of test). Unpublished $\mathrm{PhD}$ Thesis, Granada. In Spanish

Sánchez, J., \& Arellano, R. (2002). Stroke index values according to level, gender, swimming style and event race distance. In: K.E. Gianikellis (Ed.), Proceedings of the 20 International Symposium on Biomechanics in Sports, (pp. 56-59), Spain: Cacares

Tor, E., Pease, D.L., \& Ball, K.A. (2015). Key parameters of the swimming start and their relationship to start performance. Journal of Sports Sciences, 33(13), 1313-1321.

Vilas-Boas, J.P., Cruz, M.J., Sousa, F., Conceicao, F., Fernandes, R., \& Carvahlo, J.M. (2003). Biomechanics analysis of ventral swimming starts: Comparison of the grab start with two track start techniques. In: J.C. Chatard (Ed.), Biomechanics and Medicine in Swimming IX, (pp. 249-253), Saint Etienne: University of Saint Etienne, France. 


\section{RAZLIKE U SPECIFIČNO MOTORIČKIM SPOSOBNOSTIMA KOD ELITNIH PLIVAČA U ODNOSU NA POSTIGNUTE REZULTATE}

Cilj ovog istraživanja je bio da se utvrdi razlika u specifično motoričkim sposobnostima kod plivača u odnosu na postignute rezultate u disciplinama 50 i 100 metara slobodnim stilom. Ukupni uzorak obuhvaćen ovim istraživanjem činilo je 40 plivača koji su podeljeni klaster analizom ( $K$ Means Cluster Analysis) na tri grupe u odnosu na postignute rezultate u disciplini $50 \mathrm{~m}$ slobodnim stilom (G1_50, T50=23.53 $\pm 27 s, n=6$; G2_50, T50=24.54 $\pm 33 s, n=18 ; G 3 \_50, T 50=25.52 \pm 33 s$, $n=16)$, i 55 plivača u disciplini $100 \mathrm{~m}$, takođe podeljenih u tri grupe $\left(G 1 \_100, T 100=50.99 \pm 82 \mathrm{~s}\right.$, $n=10 ; \quad G 2 \_100, \quad T 100=53.41 \pm 48 s, \quad n=17 ; \quad G 3 \_100, \quad T 100=56.13 \pm 1.32$ s, $\left.n=28\right)$. Rezultati sprovedenog istraživanja pokazuju da postoji razlika u specifično motoričkim sposobnostima u odnosu na postignute rezultate $u$ disciplini 50 metara, i to: t10_50 $(F=16.79, p=.000)$, SL2_50 $(F=4.44, p=.019)$ i SI2_50 $(F=13.49, p=0.000)$, takođe $i$ u disciplini 100 metara, $i$ to: $110 \_100$ $(F=36.45, p=.000), S L 1 \_100(F=5.77, p=.005), S L 2 \_100(F=17.47, p=.000), S L 3 \_100(F=7.72$, $p=.001), S L 4 \_100(F=9.84, p=.000), S I 1 \_100(F=5.12, p=.009), S I 2 \_100(F=45.97, p=.000)$, SI3_100 $(F=13.86, p=.000), S I 4 \_100(F=31.23, p=.000), S R 1 \_100(F=4.12, p=.022) i S R 2 \_100$ $(F=6.37, p=.003)$. Na osnovu ovakvih rezultata može se zaključiti da plivači koji imaju bolju kontrolu nad specifično motoričkim sposobnostima u toku svih segmenata trke, u koje spadaju dužina zaveslaja, indeks zaveslaja i ritam zaveslaja imaju potencijala da budu brži u disciplinama 50-m i 100-m slobodnim stilom.

Ključne reči: plivanje, ritam zaveslaja, indeks zaveslaja, dužina zaveslaja 